\title{
KNOWLEDGE, PRACTICE AND PERCEIVED BARRIER OF PRESSURE ULCER PREVENTION AMONG NURSES IN A PUBLIC HOSPITAL IN SELANGOR
}

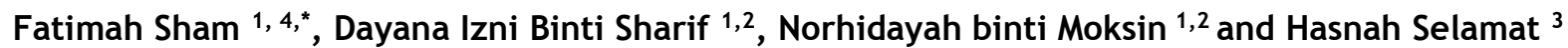 \\ ${ }^{1}$ Faculty of Health Science, Puncak Alam Campus, Universiti Teknologi MARA (UiTM), 42300 Malaysia \\ 2 UiTM Medical Specialist Centre, Faculty of Medicine, Universiti Teknologi MARA, Sungai Buloh Campus, Selangor \\ Branch,47000, Jln Hospital, Sungai Buloh, Selangor, MALAYSIA \\ ${ }^{3}$ Nursing Unit, Hospital Sungai Buloh, Jalan Hospital, 47000, Sungai Buloh, Selangor \\ ${ }^{4}$ Maternofetal and Embryology Research Group, Faculty of Medicine, Sungai Buloh Campus, Universiti Teknologi \\ MARA (UiTM), 47000 Malaysia \\ * Corresponding author: Fatimah Sham \\ E-mail: fatimah2886@.uitm.edu.my
}

\begin{abstract}
Pressure Ulcers (PUs) are a significant health problem for hospitalized patients associated with the leading cause of morbidity and mortality. Each year, more than 2.5 million patients suffer from PUs, and about 60,000 people died due to complications of PUs globally. Although PUs brings devastating consequences, fortunately, it can be prevented. The prevention of PUs represents a marker of quality of care and safety of a health-care organization. PUs prevention indeed needs multidisciplinary collaboration management; however, nurses' role is more significant as they are the frontline in providing patient care. This study aimed to assess knowledge, practice, and perceived barriers of PUs prevention among nurses in a Public Hospital in Selangor. A descriptive and cross-sectional study was used to obtain the data. A purposive sample of 220 nurses had been recruited from ICU, CCU, medical, surgical, and orthopedic wards at Public Hospital in Selangor. Data were obtained from self-administered questionnaires. The result was analyzed using the IBM Statistical Packages for Social Science (SPSS) Window Version 23. This study revealed that the respondents had adequate knowledge (95.0\%) and good practice (96.8\%) of PUs prevention. Heavy workload and inadequate staff were mostly cited as the barrier of PUs prevention. In overall, the respondents' knowledge and practice were good; however, deficits in a particular area of knowledge and practice of PUs prevention still exist. The hospital and nursing department should organize continuous education programs and inhouse training in related field to optimized nurses' knowledge and practice regarding pressure ulcer prevention and management
\end{abstract}

Keywords: Pressure Ulcers prevention, Nurses, Knowledge, Practice, Perceived barriers

\section{INTRODUCTION}

Pressure Ulcers (PUs) defined as localized injury to the skin and/or underlying tissues usually over a bony prominence, as a result of pressure, or pressure in combination with shear and/or friction ${ }^{1}$. PUs is a significant health problem for hospitalized patients that reduce the quality of life of patients associated with a significant cause of morbidity and mortality and give a substantial burden on patients and their caregivers ${ }^{2}$. The prevention of PUs represents a marker of quality of care and safety of health-care organization and facilities. PUs is a primary nurse-sensitive outcome. Hence, nursing care has a significant effect on PUs development and prevention ${ }^{3}$. PUs prevention and care indeed need multidisciplinary collaboration management ${ }^{4,17}$. However, nurses' role is more significant as they are the frontline in providing patient care. Knowledge is an important key to allow the nurses to understand the patient better and to provide higher quality care. Nurses need knowledge to assess, plan, implement, and evaluate care $^{5}$. Besides knowledgeable and good practice of PUs prevention among nurses, the health facilities itself also play an essential role in the prevention of PUs. PUs has terrible consequences on a patient's quality of life. The extent and depth of impacts related to having a PUs on quality of life are significant, it impacted the patient physically, psychologically, emotionally, spiritually, socially, and financially ${ }^{6}$.

Study done by Kim \& Lee (2019), aimed to assess the nurses' level of knowledge, attitude, and performance of PUs prevention in long term care facilities found that the nurses had moderate level of knowledge of PUs prevention. In their study, they suggested to have an appropriate guidelines and education programmed to improve the nurse's level of knowledge ${ }^{7}$. Studies conducted in Ethiopia by Nuru, Zewdu, Amsalu, \& Mehretie, (2015), to assess knowledge and practice of nurses toward prevention of PUs and associated factors. The result shown that knowledge and practiced of the nurses' regarding PUs prevention was inadequate ${ }^{2}$. Another two years later, the same study was conducted Ebi et al. (2017) which aimed to assess knowledge and perceived barriers to pressure ulcer prevention among nurses in public hospitals; revealed that most of the nurses who participate in the study had an unsatisfactory knowledge level (63.85\%) in PUs prevention. The researchers recommend the continuity of in-service training 
and educational program for nurses to enhance their knowledge and practice regarding the PU Prevention? ${ }^{7}$.

Another study done by Uba et al. 2015 in Nigeria to assess nurses' knowledge, attitude, and practice of pressure ulcer prevention showed that nurses had a low level of knowledge $(61.78 \%)$. The researchers suggest that nurses should increase their knowledge regarding the prevention of PUs, which will lead to an improvement in nursing practice and prevent PUs development ${ }^{8}$. However, there were studies had contradicted result such as a reported in Turkey 2016, Köse et al. revealed that the level of knowledge of Intensive Care Unit nurses concerning preventive interventions for Pus found that majority of the nurses' knowledge found to be good $^{9}$. While, Dilie \& Mengistu in their study to assessment of nurses' knowledge, attitude, and perceived barriers to expressed PUs prevention practice found that $120(61.2 \%)$ of the participants had adequate knowledge about PUs prevention practice while $76(38.8 \%)$ of them had inadequate knowledge. The researchers recommended the ministry to give further training to staff and provide policies and guidelines to prevent PUs in the hospitals ${ }^{10}$. On 2015, Uba et al. conducted a study in Nigeria to assess nurses' knowledge, attitude, and practice of pressure ulcer prevention. The findings of the study showed that nurses had a low level of knowledge (61.78\%). The researchers suggest that nurses should increase their knowledge regarding the prevention of PUs, which will lead to an improvement in nursing practice and prevent PUs development ${ }^{8}$.

As for preventive practice, Nuru et al. 2015 revealed that nurses' practice was inadequate in PUs prevention. The researchers mentioned that dissatisfaction with nursing leadership and insufficient staff significantly associated with the nurses' practices. In-service training, upgrading courses, and enduring availability of the facilities and equipment in some way will improve nurses' knowledge and practices ${ }^{2}$. Another study in NorthEastern, Nigeria, also found that the nurses' level of practice was low in PUs prevention. The researchers assumed that knowledge deficit; shortage of staff and unavailability of modern pressure ulcer prevention equipment might be the reasons behind the low level of practice ${ }^{8}$.

In identifying a perceived barrier, Ebi et al. have conducted a study titled Nurses' knowledge and perceived barriers to PUs prevention in Public Hospitals in Addis Ababa, Ethiopia reported that shortage of staff (83.1\%) were found to be the highest barrier to carrying out PUs prevention measures, followed by limited resources $(67.7 \%)$ and lack of guidelines (policies) about PUs prevention $(59.8 \%)^{7}$. A cross-sectional study aims to assess knowledge, attitudes, and perceived barriers to expressed PUs prevention practice conducted by Dilie and Mengistu (2015) identified that the most frequently reported barrier to carrying out PUs practices was a disproportionate nurse to patient ratio, followed by lack of job satisfaction. The researchers recommend the Health Service Managers to identify the perceived barriers minimized the barrier to PUs ulcer development ${ }^{10}$. In Jordan, Tubaishat and friends explored that the most commonly cited barriers were lack of staff followed by lack of time then medically unstable or uncooperative patients ${ }^{11}$.

Many studies from other countries showed the importance of nurses' role in preventing and caring for Pus by assessing the knowledge, practices and the barriers in PUs prevention also among nurse worldwide. In Malaysia, there is a lack of evidence concerning nurses' knowledge, and practice towards PUs and the perceived barrier to prevent PUs. Therefore, the present study aimed to assess knowledge, practice, and perceived barrier of PUs prevention among nurses in a public hospital in Selangor. The finding of this study can be a turning point and a baseline for nurses and healthcare organization to take appropriate measure for the improvement of PUs care.

\section{METHODS}

\section{Design}

A descriptive and cross-sectional study was performed.

\section{Setting and period}

The study was conducted at the Intensive Care Unit, Coronary Care Unit, medical ward, surgical ward and orthopedic ward in Public Hospital in Selangor. The study was conducted from December 2018 to May 2019.

\section{Population and sample size}

The study subjects were all 313 nurses working in the selected ward in Public Hospital and fulfilling the inclusion criteria. Using Raosoft software, sample size calculated was 220 with a $20 \%$ of dropout rate added.

\section{Eligibility criteria}

Inclusion Criteria. All nurses who directly involved in the patient care and willing to participate in the study were included in the study.

Exclusion Criteria. Administrator, educator, nurse manager and nurses who are on leave during data collection period were excluded from the study.

\section{Instruments}

This study used self-administrated questionnaires adopted from the previous studies consist of three part. The questionnaire was in English and Malay.

\section{Knowledge of Pressure Ulcer Prevention}

This was measured using Pieper-Zulkowski, Pressure Ulcer Knowledge Test. Revised May 2016 (Pieper \& Zulkowski, 2016). Respondents had to choose between "TRUE", "FALSE", and "DON'T 
KNOW". Each answer was given "1" score for correct and "0" for incorrect answer. "Don't know" answer was considered as incorrect. The total score then has been converted into a percentage. Using McDonald's standard of learning outcome measured criteria, the nurses' level of knowledge had been categorized into; very low $(<60 \%)$, low (60-69), moderate (70-79), high (80-89), and very high (90$100)$. Therefore, knowledge score of $\geq 80 \%$ was considered adequate, while a score of $<80 \%$ was considered inadequate.

\section{Practice on Pressure Ulcer Prevention}

This was measured using questionnaire with 5-point Likert scale, respondents had to answer from "STRONGLY DISAGREE" to "STRONGLY AGREE". A score above the mean was considered to have a good practice, while a score below the mean was considered as having poor practice. Negativelyworded question (no. 9) was reverse coded for analysis ${ }^{2}$.

\section{Perceived Barriers in Pressure Ulcer Prevention}

This was determined using a questionnaire; using 5point Likert scale, respondents had to answer from "STRONGLY DISAGREE" to "STRONGLY AGREE". If the respondent answered, "Strongly agrees" or "agree", it was considered as a perceived barrier and if the answer was "mixed feeling", "disagree" or "strongly disagree", it was not considered as a perceived barrier ${ }^{7}$.

\section{Validity and reliability}

Validation of the questionnaires was done by using back to a back translation from English to Malay language by Institut Terjemahan dan Buku Malaysia (ITBM). A discussion with the head of nurses of each ward involved in this study also has been done to evaluate the clarity and comprehensiveness of the questionnaire. Meanwhile, for the reliability of the questionnaire, a pilot study has been conducted by involving 30 nurses that fulfilled the inclusion criteria and exclusion criteria. The respondents for the pilot study were among nurses of Pusat Pakar Perubatan Universiti Teknologi MARA. Data from this pilot study were not included in the analysis of the sample. The Cronbach Alpha was 0.73 .

\section{Ethical Consideration}

Ethical approval has been obtained from the Research Ethics Committee of Faculty of Health Science, UiTM Research Ethics Committee, Medical Research Ethics Committee (MREC) and higher authority of Public Hospital. Respondents in this study were on a voluntary basis, and the respondents who agreed to participate were asked to sign the consent form after explanations regarding the procedure involved in this study were given. Anonymity and privacy have been assured.

\section{Data Collection}

The researcher distributed the questionnaires to the selected respondents after they finish their duty by the cooperation of the head nurse-incharge of the ward involved. All the respondents were given the consent form and the questionnaire at the same time. Respondents were given 30 minutes to complete the questionnaire after the briefing. The respondents submitted the completed questionnaire to the researcher. All questionnaire collected were rechecked by the researcher as to avoid unanswered questions.

\section{Data Analysis}

All data collected was first collected and analyzed using SPSS (Statistical Package for Social Science) Version 23.0. Descriptive statistic was used to analyze demographic data, knowledge, practice, and perceived barrier. Chi-square and independent t-test were used to study the association between knowledge with demographic data.

\section{RESULTS}

\section{Demographic Characteristics of Respondents}

Majority of the respondents were female and Malays. Mean age was 30 years old. Almost half of them $(44.5 \%)$ were from ICU, and $92.3 \%$ held a Diploma. $40 \%$ of the nurses had working experience within 1 to 5 years. Regarding the respondents' exposure to the pressure ulcer information, most of them (33.2\%) had listened to a lecture on pressure ulcer within one year and less. Almost half of the respondents $(49.6 \%)$ had read an article or book related to pressure ulcers within the previous year. Meanwhile, majority of the respondents $(76.4 \%)$ did seek out information about pressure ulcers on the web. However, fewer of them (28.6\%) had read the NPUAP/EPUAP International Pressure Ulcer Prevention and Treatment Guidelines. In relation to the frequency of pressure ulcer in the ward, half of the respondent (56.8\%) agreed that pressure ulcer's patients in their unit were frequent and another half (53.2\%) agreed for sometimes, meanwhile none of the respondents agreed for never.

\section{Knowledge on Pressure Ulcer Prevention}

Majority of the respondents (95\%) had adequate knowledge regarding pressure ulcer prevention. 97.3\% of the respondents knew that a person confined to bed should be repositioned based on individual's risk factors and the support surface's characteristics. Moreover, majority of the respondents have knowledge regarding the need of nutrient assessment (95.5\%), and adequate nutrition to the high-risk patient for pressure ulcers (96.4\%). However, the respondents have insufficient knowledge regarding the use of donut devices or ring cushions as preventive methods (15\%), and the goal of palliative care (39\%). 
Table 1: Demographics Characteristics of the Respondents $(n=220)$

\begin{tabular}{|c|c|c|}
\hline Variables & Frequency $(n)$ & Percentage (\%) \\
\hline Age (years) & $\begin{aligned} \text { Mean: } 30.13 & (\mathrm{SD}: 4.33) \\
& <30 \text { years old } \\
& 30-35\end{aligned}$ & \\
\hline \multicolumn{3}{|l|}{ Gender } \\
\hline Male & 16 & 7.3 \\
\hline Female & 204 & 92.7 \\
\hline \multicolumn{3}{|l|}{ Ward } \\
\hline Intensive Care Unit & 98 & 44.5 \\
\hline Coronary Care Unit & 9 & 4.2 \\
\hline Medical Wards & 57 & 25.9 \\
\hline Surgical Wards & 26 & 11.8 \\
\hline Orthopaedics Wards & 30 & 13.6 \\
\hline \multicolumn{3}{|l|}{ Ethnic } \\
\hline Malay & 201 & 91.4 \\
\hline Chinese & 3 & 1.4 \\
\hline Indian & 9 & 4.0 \\
\hline Others & 7 & 3.2 \\
\hline \multicolumn{3}{|l|}{ Job Grade } \\
\hline U19 & 11 & 5 \\
\hline U24 & 4 & 1.8 \\
\hline U29 & 195 & 88.6 \\
\hline U32 (KUP) & 10 & 4.6 \\
\hline \multicolumn{3}{|l|}{ Number of year practice } \\
\hline$<1$ year & 8 & 3.6 \\
\hline $1-5$ years & 88 & 40 \\
\hline$>5-10$ years & 77 & 35 \\
\hline$>10-15$ years & 38 & 17.3 \\
\hline$>15-20$ years & 9 & 4.1 \\
\hline \multicolumn{3}{|l|}{ Level of Education } \\
\hline Certificate & 15 & 6.8 \\
\hline Diploma & 203 & 92.3 \\
\hline Degree & 2 & 0.9 \\
\hline Master & 0 & 0 \\
\hline \multicolumn{3}{|c|}{ Certification in any clinical specialty } \\
\hline Yes & 54 & 24.5 \\
\hline No & 166 & 75.5 \\
\hline Variables & Frequency $(n)$ & Percentage (\%) \\
\hline \multicolumn{3}{|c|}{ Certified as wound specialist } \\
\hline Yes & 0 & 0 \\
\hline No & 220 & 100 \\
\hline \multicolumn{3}{|c|}{ When was the last time you listened to a lecture on pressure ulcers } \\
\hline 1 year or less & 73 & 33.2 \\
\hline$>1$ year but $<2$ years & 56 & 25.5 \\
\hline 2 - 3 years & 47 & 21.4 \\
\hline 4 years and above & 18 & 8.1 \\
\hline Never & 26 & 11.8 \\
\hline \multicolumn{3}{|c|}{ When was the last time you read an article or book about pressure ulcers } \\
\hline 1 year or less & 109 & 49.6 \\
\hline$>1$ year but $<2$ years & 41 & 18.6 \\
\hline 2 - 3 years & 32 & 14.5 \\
\hline 4 years and above & 26 & 11.8 \\
\hline Never & 12 & 5.5 \\
\hline \multicolumn{3}{|c|}{ Have you sought out information about pressure ulcers on the web } \\
\hline Yes & 168 & 76.4 \\
\hline No & 52 & 23.6 \\
\hline \multicolumn{3}{|c|}{ Have you read the NPUAP/EPUAP International Pressure Ulcer Prevention and Treatment Guidelines } \\
\hline Yes & 63 & 28.6 \\
\hline No & 157 & 71.4 \\
\hline \multicolumn{3}{|c|}{ How many patients with a pressure ulcer in your unit } \\
\hline Frequently & 103 & 46.8 \\
\hline Sometimes & 117 & 53.2 \\
\hline Never & 0 & 0 \\
\hline
\end{tabular}




\section{Practice on Pressure Ulcer Prevention}

Majority of the respondents $(96.8 \%)$ had good practice towards pressure ulcer prevention. The nurses had been applying a good practice of pressure ulcer prevention by paying more attention to pressure points prone for an ulcer $(M=4.17$, $\mathrm{SD}=0.50$ ), as well as, by turning a patient 2 hourly $(M=4.14, S D=0.64)$. Furthermore, the nurses also did data documentation $(M=4.06, S D=0.66)$ and advised the patient or the caregiver regarding pressure ulcer prevention $(M=4.05, S D=0.54)$.

On the contrary, the nurses possessed a poor practice such as using water-filled glove under the patient's leg $(M=2.70 S D=1.14)$, using donut-shape (ring) cushion $(M=2.79, S D=1.14)$, and practicing massage to prevent pressure ulcer $(M=2.94$, $S D=1.11)$. Moreover, the mean for the question of $I$ perform lab test, scored the lowest $(M=2.68$, $\mathrm{SD}=0.98)$.

\section{Perceived Barriers in Pressure Ulcer Prevention} A high percentage of respondents $(95 \%)$ said that heavy workload and inadequate staff were most of the barrier faced by them to carry out pressure ulcer prevention, followed by shortage of resources such as equipment and facilities (90\%) and the presence of other priorities than pressure ulcer $(87.7 \%)$.

\section{Association between Demographics Characteristics of the Respondents with Knowledge in Pressure Ulcer Prevention}

There was an association found between the working unit and adequacy of knowledge, in which Intensive Care Unit scored the highest number of respondents $(n=97 ; 44.1 \%) \quad$ with adequate knowledge compared to other units. The $p$-value is 0.001 . Meanwhile, there was no association found between the adequacy of nurses' knowledge with their age $(p=0.11)$, gender $(p=0.91)$, ethnic $(p=0.24)$, job grade $(p=0.08)$, years of practice $(p=0.19)$, level of education $(p=0.25)$, certification in any specialty $(p=0.73)$ and frequency of pressure ulcer in a unit $(p=0.25)$.

The statistical test also showed no association between knowledge and the nurses' exposure to the pressure ulcer information items; the last time listened to a lecture on pressure ulcer $(p=0.12)$, the last times read an article or book about pressure ulcers $(p=0.947)$, sought out information about pressure ulcers on the web $(p=1.00)$ and read the NPUAP/EPUAP International Pressure Ulcer Prevention and Treatment Guidelines $(p=1.00)$.

\section{DISCUSSION}

There is a total of 220 nurses have recruited to participate in this study where the age of nurses ranged from 22 to 43 years, with a mean age of 30 years old. This result show that most of the nurses are in their middle age. This study found that most of the nurses who participated were female. It is common as women monopolize the nursing profession almost entirely, and male nurses are more likely to work in the emergency unit and operating theatre. As a rule, the qualification criteria for being a staff nurse in Malaysia, especially in government hospital are diploma in nursing. This study found that most of the nurses participated was a diploma holder, who is known as a Staff Nurse. Only one-quarter of the nurses in this study had certification in the clinical specialty or post basic.

Most of the nurses participated was from one to 5 years, and 5 to 10 years of practice. It shows that most nurses are at the beginning of their careers. Regarding the nurse's exposure to the pressure ulcer information, most of them had listened to a lecture on pressure ulcer within one year, and less, almost half of them had read an article or book related to pressure ulcers within the previous year. Meanwhile, majority of the respondents did seek out information about pressure ulcers on the web. However, fewer of them had read the NPUAP/EPUAP International Pressure Ulcer Prevention and Treatment Guidelines. This is may be due to the lack of exposure on NPUAP/EPUAP in the workshop and from the curriculum syllabus. Half of the respondent agreed that pressure ulcer's patients in their unit were frequent, and another half agreed for sometimes. This result showed that with good knowledge and practices, the incident of pressure ulcer still cannot be prevented.

This study reported that most of the nurses had adequate knowledge regarding pressure ulcer prevention while only minority of them reported to had inadequate knowledge of pressure ulcer prevention. The result correspondingly to the study done in Turkey, where the nurses' knowledge was found to be good 9 . Same goes with a study done in Ethiopia, also found that the nurses had adequate knowledge of pressure ulcer prevention ${ }^{10}$. Most of them had the same working experience as the current study within 1 to 5 years. As for exposure of pressure ulcer prevention, although the result was found to be adequate, both studies showed that their nurses are less in seeking information on the pressure ulcer ${ }^{9,10}$. This current study contradicted with the previous studies done in Korea, Ethiopia, Nigeria, and Northwest Ethiopia, who found that the level of knowledge was inadequate ${ }^{7,12,9}$. 
Table 2: Nurses’ Knowledge toward Pressure Ulcer Prevention $(n=220)$

\begin{tabular}{|c|c|c|c|}
\hline \multirow{2}{*}{ No. } & \multirow{2}{*}{ Variables } & \multicolumn{2}{|c|}{ Frequency (n) / Percentage (\%) } \\
\hline & & Correct & Incorrect \\
\hline 1. & $\begin{array}{l}\text { Hot water and soap may dry the skin and increase the risk } \\
\text { for pressure ulcers. }\end{array}$ & $148(67.3)$ & $72(32.7)$ \\
\hline 2. & Chair-bound persons should be fitted for a chair cushion. & $154(70.0)$ & $66(30.0)$ \\
\hline 3. & $\begin{array}{l}\text { A person confined to bed should be repositioned based on } \\
\text { individual's risk factors and the support surface's } \\
\text { characteristics. }\end{array}$ & $214(97.3)$ & $6(2.7)$ \\
\hline 4. & $\begin{array}{l}\text { A pressure injury/ulcer scar will break down faster than } \\
\text { unwounded skin. }\end{array}$ & $208(94.5)$ & $12(5.5)$ \\
\hline 5. & The goal of palliative care is wound healing. & $39(17.7)$ & $181(82.3)$ \\
\hline 6. & Dragging the patient up in bed increases friction. & $194(88.2)$ & $26(11.8)$ \\
\hline 7. & $\begin{array}{l}\text { Small position changes may need to be used for patients who } \\
\text { cannot tolerate major shifts in body positioning. }\end{array}$ & $174(79.1)$ & $46(20.9)$ \\
\hline 8. & An incontinence patient should have a toileting care plan. & $189(85.9)$ & $31(14.1)$ \\
\hline 9. & $\begin{array}{l}\text { A pressure redistribution surface manages tissue load and } \\
\text { the climate against the skin. }\end{array}$ & $196(89.1)$ & $24(10.9)$ \\
\hline 10. & $\begin{array}{l}\text { When possible, high-protein oral nutritional supplements } \\
\text { should be used in addition to the usual diet for patients at } \\
\text { high risk for pressure injury/ulcers. }\end{array}$ & $212(96.4)$ & $8(3.6)$ \\
\hline 11. & $\begin{array}{l}\text { The home care setting has unique considerations for support } \\
\text { surface selection. }\end{array}$ & $163(74.1)$ & $57(25.9)$ \\
\hline 12. & $\begin{array}{l}\text { Donut devices/ring cushions help to prevent pressure } \\
\text { injury/ulcers. }\end{array}$ & $15(6.8)$ & $205(93.2)$ \\
\hline 13. & $\begin{array}{l}\text { A specialty bed should be used on areas at risk for shear } \\
\text { injury. }\end{array}$ & $45(20.5)$ & $175(79.5)$ \\
\hline 14. & $\begin{array}{l}\text { Persons at risk for pressure injury/ulcers should be } \\
\text { nutritionally assessed (i.e., weight, nutrition intake, blood } \\
\text { work). }\end{array}$ & $210(95.5)$ & $10(4.5)$ \\
\hline 15. & $\begin{array}{l}\text { Critical care patients may need slow, gradual turning } \\
\text { because of being hemodynamically unstable. }\end{array}$ & $203(92.3)$ & $17(7.7)$ \\
\hline 16. & $\begin{array}{l}\text { Staff education alone may reduce the incidence of pressure } \\
\text { injury/ulcers. }\end{array}$ & $130(59.1)$ & $90(40.9)$ \\
\hline 17. & $\begin{array}{l}\text { A footstool/footrest should not be used for an immobile } \\
\text { patient whose feet do not reach the floor. }\end{array}$ & $74(33.6)$ & $146(66.4)$ \\
\hline 18. & $\begin{array}{l}\text { Massage of bony prominences is essential for quality skin } \\
\text { care. }\end{array}$ & $42(19.1)$ & 178 (80.9) \\
\hline 19. & $\begin{array}{l}\text { Poor posture in a wheelchair may be the cause of a pressure } \\
\text { injury/ulcer. }\end{array}$ & $142(64.5)$ & $78(35.5)$ \\
\hline 20. & $\begin{array}{l}\text { For persons who have incontinence, skin cleaning should } \\
\text { occur at the time of soiling and at routine intervals. }\end{array}$ & $208(94.5)$ & $12(5.5)$ \\
\hline 21. & $\begin{array}{l}\text { Patients who are spinal cord injured need knowledge about } \\
\text { pressure injury/ulcer prevention and self-care. }\end{array}$ & $206(93.6)$ & $14(6.4)$ \\
\hline 22. & $\begin{array}{l}\text { Persons, who are immobile and can be taught, should shift } \\
\text { their weight every } 30 \text { minutes while sitting in a chair. }\end{array}$ & 35 (15.9) & $185(84.1)$ \\
\hline 23. & $\begin{array}{l}\text { Selection of a support surface should only consider the } \\
\text { person's level of pressure injury/ulcer risk. }\end{array}$ & $72(32.7)$ & $148(67.3)$ \\
\hline 24. & $\begin{array}{l}\text { It is not necessary to have the patient with a spinal cord } \\
\text { injury evaluated for seating. }\end{array}$ & $130(59.1)$ & $90(40.9)$ \\
\hline 25. & $\begin{array}{l}\text { To help prevent pressure injury/ulcer, the head of the bed } \\
\text { should be elevated at a } 45 \text {-degree angle or higher. }\end{array}$ & $129(58.6)$ & $91(41.4)$ \\
\hline 26. & Urinary catheter tubing should be positioned under the leg. & $138(62.7)$ & $82(37.3)$ \\
\hline 27. & $\begin{array}{l}\text { Pressure injury/ulcer may be avoided in patients who are } \\
\text { obese with the use of properly sized equipment. }\end{array}$ & $176(80.0)$ & $44(20.0)$ \\
\hline 28. & $\begin{array}{l}\text { Pressure injury/ulcers are a lifelong concern for a person } \\
\text { who is spinal cord injured. }\end{array}$ & $205(93.2)$ & $15(6.8)$ \\
\hline
\end{tabular}


Table 3: Nurses' Practice on Pressure Ulcer Prevention $(n=220)$

\begin{tabular}{|c|c|c|c|c|c|c|c|}
\hline \multirow[b]{2}{*}{ No. } & \multirow[b]{2}{*}{ Variables } & \multicolumn{6}{|c|}{ Frequency (n) / Percentage (\%) } \\
\hline & & $\begin{array}{l}\text { Strongly } \\
\text { Agree } \\
(5)\end{array}$ & $\begin{array}{l}\text { Agree } \\
(4)\end{array}$ & $\begin{array}{l}\text { Mixed } \\
\text { Feeling } \\
(3)\end{array}$ & $\begin{array}{l}\text { Disagree } \\
\quad(2)\end{array}$ & $\begin{array}{l}\text { Strongly } \\
\text { Disagree } \\
\text { (1) }\end{array}$ & Mean (SD) \\
\hline 1 & $\begin{array}{l}\text { I observe how } \\
\text { other nurses assess } \\
\text { the risk factors }\end{array}$ & $11(5.0)$ & $156(70.9)$ & $25(11.4)$ & $17(7.7)$ & $11(5.0)$ & $3.63(0.89)$ \\
\hline 2 & $\begin{array}{l}\text { I identify common } \\
\text { contributing factors }\end{array}$ & $22(10.0)$ & $174(79.1)$ & $13(5.9)$ & $10(4.5)$ & $1(0.5)$ & $3.94(0.62)$ \\
\hline 3 & $\begin{array}{l}\text { I do a skin } \\
\text { assessment }\end{array}$ & $35(15.9)$ & 167 (75.9) & $11(5.0)$ & $4(1.8)$ & $3(1.4)$ & $4.03(0.64)$ \\
\hline 4 & $\begin{array}{l}\text { I use risk } \\
\text { assessment scale }\end{array}$ & $38(17.3)$ & $154(70.0)$ & $19(8.6)$ & $6(2.7)$ & $3(1.4)$ & $3.99(0.70)$ \\
\hline 5 & I document all data & $47(21.4)$ & $148(67.3)$ & $17(7.7)$ & $8(3.6)$ & $0(0)$ & $4.06(0.66)$ \\
\hline 6 & $\begin{array}{l}\text { I assess and provide } \\
\text { management of } \\
\text { pain }\end{array}$ & $26(11.8)$ & $179(81.3)$ & $13(5.9)$ & $1(0.5)$ & $1(0.5)$ & $4.04(0.49)$ \\
\hline 7 & $\begin{array}{l}\text { I perform skin care } \\
\text { as a routine work }\end{array}$ & $21(9.5)$ & $169(76.8)$ & $20(9.1)$ & $10(4.6)$ & $0(0)$ & $3.91(0.60)$ \\
\hline 8 & $\begin{array}{l}\text { I place the pillow } \\
\text { under the patient's } \\
\text { leg }\end{array}$ & $21(9.5)$ & $157(71.4)$ & $26(11.8)$ & $14(6.4)$ & $2(0.9)$ & $3.82(0.72)$ \\
\hline 9 & $\begin{array}{l}\text { I use water filled } \\
\text { glove under the } \\
\text { patient's leg }\end{array}$ & $4(1.8)$ & $74(33.6)$ & $29(13.2)$ & 79 (35.9) & 34 (15.5) & $2.70(1.14)$ \\
\hline 10 & $\begin{array}{l}\text { I use or advice } \\
\text { caregiver to use } \\
\text { creams or oils }\end{array}$ & $37(16.8)$ & $151(68.6)$ & $13(5.9)$ & $15(6.9)$ & $4(1.8)$ & $3.92(0.81)$ \\
\hline 11 & $\begin{array}{l}\text { I pay more } \\
\text { attention to } \\
\text { pressure points }\end{array}$ & $46(20.8)$ & $168(76.4)$ & $3(1.4)$ & $3(1.4)$ & $0(0)$ & $4.17(0.50)$ \\
\hline 12 & I perform lab test & $5(2.3)$ & $49(22.3)$ & $52(23.6)$ & $98(44.5)$ & $16(7.3)$ & $2.68(0.98)$ \\
\hline 13 & $\begin{array}{l}\text { I provide vitamin } \\
\text { and food }\end{array}$ & $14(6.4)$ & $153(69.5)$ & $14(6.4)$ & $34(15.4)$ & $5(2.3)$ & $3.62(0.90)$ \\
\hline 14 & $\begin{array}{l}\text { I monitor a protein } \\
\text { and calorie diet }\end{array}$ & $16(7.2)$ & $150(68.2)$ & $31(14.1)$ & $20(9.1)$ & $3(1.4)$ & $3.71(0.79)$ \\
\hline 15 & I avoid dragging & $37(16.8)$ & $151(68.6)$ & 24 (10.9) & $7(3.2)$ & $1(0.5)$ & $3.98(0.67)$ \\
\hline 16 & $\begin{array}{l}\text { I always use a } \\
\text { special mattress }\end{array}$ & $32(14.5)$ & $148(67.3)$ & $24(10.9)$ & $15(6.8)$ & $1(0.5)$ & $3.89(0.75)$ \\
\hline 17 & I avoid massage & $14(6.4)$ & 67 (30.5) & $49(22.3)$ & 71 (32.3) & $19(8.5)$ & $2.94(1.11)$ \\
\hline 18 & $\begin{array}{l}\text { I avoid using donut } \\
\text { - shape (ring) } \\
\text { cushion }\end{array}$ & $17(7.7)$ & $55(25.0)$ & $31(14.1)$ & $99(45.0)$ & $18(8.2)$ & $2.79(1.14)$ \\
\hline 19 & $\begin{array}{l}\text { I turn a patient } \\
\text { position every two } \\
\text { hours }\end{array}$ & $58(26.4)$ & 139 (63.2) & $19(8.6)$ & $4(1.8)$ & $0(0)$ & $4.14(0.64)$ \\
\hline 20 & $\begin{array}{l}\text { I put pillows under } \\
\text { the patient's leg } \\
\text { ankle }\end{array}$ & $18(8.2)$ & $162(73.6)$ & $26(11.8)$ & $13(5.9)$ & $1(0.5)$ & $3.83(0.67)$ \\
\hline 21 & $\begin{array}{l}\text { I always attend } \\
\text { seminars }\end{array}$ & $5(2.3)$ & 94 (42.7) & $42(19.1)$ & $65(29.5)$ & $14(6.4)$ & $3.05(1.04)$ \\
\hline 22 & $\begin{array}{l}\text { I give advice to the } \\
\text { patient or } \\
\text { caregiver }\end{array}$ & $33(15.0)$ & $170(77.3)$ & $12(5.4)$ & $5(2.3)$ & $0(0)$ & $4.05(0.54)$ \\
\hline
\end{tabular}


Table 4: Nurses' Perceived Barriers in Pressure Ulcer Prevention $(n=220)$

\begin{tabular}{llrr}
\hline No. & \multicolumn{1}{c}{ Variables } & \multicolumn{2}{c}{ Frequency (n) / Percentage (\%) } \\
\cline { 3 - 4 } & & \multicolumn{1}{c}{$\begin{array}{c}\text { Perceived } \\
\text { Barriers }\end{array}$} & $\begin{array}{c}\text { Not Perceived } \\
\text { Barriers }\end{array}$ \\
\hline 1. & Poor access to literature & $153(69.5)$ & $67(30.5)$ \\
2. & Heavy workload and inadequate staff & $209(95)$ & $11(5)$ \\
3. & Lack of universal guideline on prevention of pressure & $129(58.6)$ & $91(41.4)$ \\
& ulcer & & \\
4. & Inadequate training coverage of pressure ulcer & $143(65)$ & $77(35)$ \\
& prevention & $167(75.9)$ & $53(24.1)$ \\
5. & Uncooperative patients & $122(55.5)$ & $98(44.5)$ \\
6. & Lack of job satisfaction in the nursing profession & $193(87.7)$ & $27(12.3)$ \\
7. & Presence of other priorities than pressure ulcer & $198(90)$ & $22(10)$ \\
8. & Shortage of resources (equipment, facilities) & $87(39.5)$ & $133(60.5)$ \\
9. & Inadequate knowledge about pressure ulcer among & $92(41.8)$ & $128(58.2)$ \\
& nurses & $43(19.5)$ & $177(80.5)$ \\
10. & Lack of multidisciplinary among staff nurses & $167(75.9)$ & $53(24.1)$ \\
11. & I don't have any challenge & $121(55)$ & $99(45)$ \\
12. & Unstable patient & $70(31.8)$ & $150(68.2)$ \\
13. & Problems with the assessment tool & & \\
14. & Forget the assessment & &
\end{tabular}

Having a bachelor's degree are not guaranteed that the result of knowledge will be good. This was proven by the studies done in Korea, Ethiopia, and Northwest Ethiopia, where most of the nurses participated in the study was a bachelor's degree holder ${ }^{7,12,9}$. The result showed that the level of knowledge was inadequate.

As for the working experience, more extended working experience does not reflect good knowledge of the nurses. This is proven by the study done in Ebi et al., where most of the nurses were working for more than five years, and the result of the knowledge was found to be inadequate ${ }^{7}$. The question that answered correctly by most of the nurses was ' $a$ person confined to bed should be repositioned based on the individual's risk factors and the support surface's characteristics', second question was 'when possible, high-protein oral nutritional supplements should be used in addition to the usual diet for patients at high risk for pressure injury/ulcer', and 'persons at risk for pressure injury/ulcers should be nutritionally assessed (i.e., weight, nutrition intake, blood work)'. Based on this result, this study showed that nurses in this area are knowledgeable regarding risk factor of pressure ulcer development and the nutritional requirement for the patient. This result similar to the study done by Ebi et al., where most of the nurses answered correctly to the question of the risk factor of pressure ulcer and adequate nutritional intake during illnesses ${ }^{7}$. On the other hand, most of the nurses answered wrongly to the question of donut devices/ring cushions help to prevent pressure injury/ulcers. This result similar to the study done in Brazil, where more than half of the nurses answered the same question wrongly ${ }^{13}$.

According to the EPUAP (European Pressure Ulcer Advisory Panel and National Pressure Ulcer Advisory Panel, 2014), a ring or donut-shape devices are can no longer be used as the edge of the devices create an area of high pressure which may contribute to the pressure ulcer's development ${ }^{1}$. The possible reason for this consequence may due to the result found in this study that only fewer of the nurses in this area had read the NPUAP/EPUAP International Pressure Ulcer Prevention and Treatment Guidelines. The rest of them was not aware with new recommendation by NPUAP/EPUAP.

This study reported that about $96.8 \%$ of the nurses had good practice towards pressure ulcer prevention in a public hospital in Selangor, while only $3.2 \%$ of the nurses reported to had poor practice on pressure ulcer prevention. This result was confirmed to be contradicted with the previous studies done by Nuru et al. (2015), and in Nigeria by Uba et al. Both studies revealed that nurses had inadequate practices in their $\operatorname{area}^{2,8}$. Good practices of the nurses in Selangor may be due to their adequate knowledge regarding pressure ulcer prevention. Nurses had been applying the good practice of pressure ulcer prevention by paying more attention to pressure points prone to the ulcer, as well as, by turning a patient two hourly. Furthermore, the nurses also did data documentation and gave advice to the patient or the caregiver regarding pressure ulcer prevention. 
Table 5: Association between Demographics Characteristics of the Respondents with Knowledge in Pressure Ulcer Prevention $(n=220)$

\begin{tabular}{|c|c|c|c|}
\hline \multirow[t]{2}{*}{ Variables } & \multicolumn{2}{|l|}{$\begin{array}{r}\text { Frequency }(n) / \\
(\%)\end{array}$} & \multirow[t]{2}{*}{$\begin{array}{c}\text { Statistical } \\
\text { Test }(p \text {-value })\end{array}$} \\
\hline & Adequate & Inadequate & \\
\hline \multirow{2}{*}{\multicolumn{3}{|c|}{$\begin{array}{l}\text { Age (years) } \\
\text { Gender }\end{array}$}} & $23.81(0.11)^{*}$ \\
\hline & & & $0.91(1.00)^{*}$ \\
\hline Male & $16(7.3)$ & $0(0)$ & \\
\hline Female & $193(87.7)$ & $11(5.0)$ & \\
\hline \multicolumn{3}{|l|}{ Ward } & $17.10(0.01)^{*}$ \\
\hline Intensive Care Unit & $97(44.1)$ & $1(0.5)$ & \\
\hline Coronary Care Unit & $9(4.1)$ & $0(0)$ & \\
\hline Medical Ward & $54(24.5)$ & $3(1.4)$ & \\
\hline Surgical Ward & $26(11.8)$ & $0(0)$ & \\
\hline Orthopaedics Ward & $23(10.5)$ & $7(3.2)$ & \\
\hline \multicolumn{3}{|l|}{ Ethnic } & $4.02(0.24)^{*}$ \\
\hline Malay & $191(86.8)$ & $10(4.5)$ & \\
\hline Chinese & $2(0.9)$ & $1(0.5)$ & \\
\hline Indian & $9(4.1)$ & $0(0)$ & \\
\hline Others & $7(3.2)$ & $0(0)$ & \\
\hline \multicolumn{3}{|l|}{ Job Grade } & $5.77(0.08)^{*}$ \\
\hline U19 & $10(4.5)$ & $1(0.5)$ & \\
\hline U24 & $3(1.4)$ & $1(0.5)$ & \\
\hline U29 & $187(85.0)$ & $8(3.6)$ & \\
\hline U32 (KUP) & $9(4.1)$ & $1(0.5)$ & \\
\hline \multicolumn{3}{|l|}{ Number of year practice } & $5.27(0.19)^{*}$ \\
\hline$<1$ year & $8(3.6)$ & $0(0)$ & \\
\hline $1-5$ years & $86(39.1)$ & $2(0.9)$ & \\
\hline$>5-10$ years & $70(31.8)$ & $7(3.2)$ & \\
\hline$>10-15$ years & 37 (16.8) & $1(0.5)$ & \\
\hline$>15-20$ years & $8(3.6)$ & $1(0.5)$ & \\
\hline \multicolumn{3}{|l|}{ Level of Education } & $3.26(0.25)^{*}$ \\
\hline Certificate & $13(5.9)$ & $2(0.9)$ & \\
\hline Diploma & $194(88.2)$ & $9(4.1)$ & \\
\hline Degree & $2(0.9)$ & $0(0)$ & \\
\hline Master & $0(0)$ & $0(0)$ & \\
\hline \multicolumn{3}{|c|}{ Certification in any clinical specialty } & $0.05(0.73)^{*}$ \\
\hline Yes & $51(23.2)$ & $3(1.4)$ & \\
\hline No & $158(71.8)$ & $8(3.6)$ & \\
\hline \multicolumn{3}{|c|}{ When was the last time you listened to a lecture on pressure ulcers } & $6.39(0.12)^{*}$ \\
\hline 1 year or less & $70(31.8)$ & $3(1.4)$ & \\
\hline$>1$ year but $<2$ years & $55(25.0)$ & $1(0.5)$ & \\
\hline $2-3$ years & $42(19.1)$ & $5(2.3)$ & \\
\hline 4 years and above & $16(7.3)$ & $2(0.9)$ & \\
\hline Never & $26(11.8)$ & $0(0)$ & \\
\hline \multicolumn{3}{|c|}{$\begin{array}{l}\text { When was the last time you read an article or book about } \\
\text { pressure ulcers }\end{array}$} & $0.99(0.95)^{*}$ \\
\hline 1 year or less & $103(46.8)$ & $6(2.7)$ & \\
\hline$>1$ year but $<2$ years & $39(17.7)$ & $2(0.9)$ & \\
\hline $2-3$ years & $31(14.1)$ & $1(0.5)$ & \\
\hline 4 years and above & $24(10.9)$ & $2(0.9)$ & \\
\hline Never & $12(5.5)$ & $0(0)$ & \\
\hline \multicolumn{3}{|c|}{ Have you sought out information about pressure ulcers on the web } & $0.19(1.00)^{*}$ \\
\hline Yes & $159(72.3)$ & $9(4.1)$ & \\
\hline No & $50(22.7)$ & $2(0.9)$ & \\
\hline \multicolumn{3}{|c|}{$\begin{array}{l}\text { Have you read the NPUAP/EPUAP International Pressure Ulcer Prevention and Treatment } \\
\text { Guidelines }\end{array}$} & $0.01(1.00)^{*}$ \\
\hline Yes & $60(27.3)$ & $3(1.4)$ & \\
\hline No & $149(67.7)$ & $8(3.6)$ & \\
\hline \multicolumn{3}{|c|}{ How many patients with a pressure ulcer in your unit } & $1.78(0.23)^{*}$ \\
\hline Frequently & $100(45.5)$ & $3(1.4)$ & \\
\hline Sometimes & 109 (49.5) & $8(3.6)$ & \\
\hline Never & $0(0)$ & $0(0)$ & \\
\hline
\end{tabular}


The nurses in this study possessed a poor practice where more than half of them still using donutshape (ring) cushion on the patient. The nurses also showed poor practiced on performing lab test and more than half of them using water-filled glove under the patient's leg similar with the study done in Northwest Ethiopia ${ }^{2}$. The possible reason for this consequence may be due to the result that found in this study that only fewer of the nurses in this area had read the NPUAP/EPUAP International Pressure Ulcer Prevention and Treatment Guidelines. This result was contradicted with the nurses in Nigeria, where most of them were avoiding usage of donut shape cushion in their practice ${ }^{4}$.

Majority of the nurses in this study said that heavy workload and inadequate staff were most of the barrier faced by them to carry out pressure ulcer prevention. It followed by a shortage of resources such as equipment and facilities where $90 \%$ of them was agreed on that. A similar finding was found in the study conducted by Uba et al. (2015) and Mwebaza, Katende, Groves, \& Nankumbi (2014) ${ }^{8,14}$. Lastly, $87 \%$ of the nurses in this study agreed that the presence of other priorities was the barriers to pressure ulcer prevention. In the same way with the nurses in Ethiopia, who also agreed on the barrier, however, Mwebaza et al. (2014), stated that the uncooperative patient was among the highest barriers in preventing pressure ulcers ${ }^{2,4}$.

In this study, there was an association found between the working unit and adequacy of knowledge, in which Intensive Care Unit scored the highest number of nurses $(n=97 ; 44.1 \%)$ with adequate knowledge compared to other units. The $\mathrm{p}$-value is 0.001 . This result related to the study from Brazil, were nurses who worked in ICU had good knowledge compares to other units where the $\mathrm{p}$-value is $0.002^{13}$. However, for the current study, this significant difference was found to be biased as most of the respondents in this study was a nurse from ICU. As for other demographic characteristics, there was no association found between the adequacies of nurses' knowledge with other demographic characteristic. This study finding similar with the study done in Nepal by Shrestha \& Shrestha (2016), and a study done by Suleman et al. reported that there was no significant association was found between the level of knowledge of the nurses with the demographic variables $^{15,16}$. The statistical analysis revealed that there was no significant association between nurses' practice score with demographic characteristics.

\section{CONCLUSION}

This study was conducted to determine the level of knowledge, practice, and perceived barriers towards pressure ulcer prevention among nurses in a public hospital in Selangor. Moreover, this research was also done to find the association between knowledge with the demographic characteristic of the nurses on pressure ulcer prevention. The data were collected using selfadministered questionnaires to the 220 nurses in a public hospital in Selangor. The result appeared that the nurses had an adequate level of knowledge and good practice towards pressure ulcer prevention. However, deficits in a certain area of knowledge and practice of PUs prevention still exist. Perceived barriers to pressure ulcer prevention also measured. Good knowledge and practice could be affected on the existing barrier related to heavy workload and inadequate staff. Association between knowledge on pressure ulcer prevention with the demographic characteristic of the nurses showed no significant association. As a recommendation, the hospital and nursing department should organize continuous education programs and in-house training in related field to optimized nurses' knowledge and practice regarding pressure ulcer prevention and management.

\section{ACKNOWLEDGEMENT}

The authors gratefully acknowledge the Director General of Health Malaysia for his permission to conduct and publish this article. We would like to thanks to all the nurses involved in the study including the Nursing Unit and the Clinical Research Centre (CRC) of this Government Hospital and Universiti Teknologi MARA, Malaysia.

\section{REFERENCES}

1. European Pressure Ulcer Advisory Panel and National Pressure Ulcer Advisory Panel, P. P. P. I. A. (2014). Prevention and Treatment of Pressure Ulcers: Quick Reference Guide. Clinical Practice Guideline.

2. Nuru, N., Zewdu, F., Amsalu, S., \& Mehretie, Y. (2015). Knowledge and practice of nurses towards prevention of pressure ulcer and associated factors in Gondar University Hospital, Northwest Ethiopia. BMC Nursing, 14(1), 1-8. https: / /doi.org/10.1186/s12912-015-0076-8

3. Lyder, C. H., \& Ayello, E. a. (2008). Pressure Ulcers: A Patient Safety Issue. Patient Safety and Quality: An EvidenceBased Handbook for Nurses, 268-299. https: / /doi.org/NBK2650 [bookaccession]

4. Zeh, M., Moore, Z. E., Webster, J., \& Samuriwo, R. (2015). Wound-care teams for preventing and treating pressure ulcers (Review), https://doi.org/10.1002/14651858.CD0110 11.pub2

5. Finkelman, A., \& Kenner, C. (2016). The Essence of Nursing: Knowledge and Caring. Professional Nursing Concepts: Competencies for Qualities Leadership, 53- 
83.

Retrieved

from

http://books.google.com/books?id=kGrsXN gaYuMC\&pgis $=1$

6. Repić, G., \& Ivanović, S. (2014). Pressure Ulcers and Their Impact on Quality of Life. Acta Medica Medianae, 53(4), 75-80. https://doi.org/10.5633/amm.2014.0412

7. Ebi, W. E., Menji, Z. A., \& Hunde, B. M. (2017). Nurses' knowledge and Perceived Barriers About Pressure Ulcer Prevention for Admitted Patients in Public Hospitals in Addis Ababa, Ethiopia. Http://Www.Sciencepublishinggroup.Com, 5(4), 1. https://doi.org/10.11648/J.AJIM.S.2017050 401.11

8. Uba, M., Alh, F., \& R. Kever t al. (2015). Dearth of literature on barriers to provision of psychiatric nursing care in Nigeria: Findings from a literature review.

9. Köse, I., Yeşil, P., Öztunc, G., \& Eskimez, Z. (2016). Knowledge of Nurses Working in Intensive Care Units in Relation to Preventive Interventions for Pressure Ulcer. International Journal of Caring Scieces, 9(2), 677-687.

10. Dilie, A., \& Mengistu, D. (2015). Assessment of Nurses ' Knowledge, Attitude, and Perceived Barriers to Expressed Pressure Ulcer Prevention Practice in Addis Ababa Government Hospitals , Addis Ababa , Ethiopia , 2015. Advances in Nursing, 2015, 1-11.

https://doi.org/10.1155/2015/796927

11. Tubaishat, A., Aljezawi, M., \& Al Qadire, M. (2013). Nurses' attitudes and perceived barriers to pressure ulcer prevention in Jordan. Journal of Wound Care, 22(9), 490497.

https://doi.org/10.12968/jowc.2013.22.9.4 90
12. Kim, J. Y., \& Lee, Y. J. (2019). A study on the nursing knowledge, attitude, and performance towards pressure ulcer prevention among nurses in Korea longterm care facilities. International Wound Journal, 16(September 2018), 29-35. https://doi.org/10.1111/iwj.13021

13. Chianca, T. C. M., Rezende, J. P. R., Borges, E. L., Nogueira, V. L., \& Caliri, M. H. L. (2010). Tânia Couto Machado Chianca, $\mathrm{PhD}, \mathrm{RN}$; Jomara Figueiredo Pinto Rezende, RN; Eline Lima Borges, PhD, RN, CWET; Vera Lucia Nogueira, RN; and Maria Helena Larcher Caliri, PhD, RN. 56(10), 58-64.

14. Mwebaza, I., Katende, G., Groves, S., \& Nankumbi, J. (2014). Nurses' Knowledge, Practices, and Barriers in Care of Patients with Pressure Ulcers in a Ugandan Teaching Hospital. Nursing Research and Practice, 2014, 1-6. https://doi.org/10.1155/2014/973602

15. Shrestha, N., \& Shrestha, P. (2016). Knowledge of Pressure Ulcer Management among Nurses. 09(02), 47-51.

16. Suleman, Muna, Rahman, Abdel, Kharabsheh, Al, ... Rn, M. Y. N. S. (2014). Exploring Nurses, Knowledge and Perceived Barriers to Carry Out Pressure Ulcer Prevention and Treatment, Documentation, and Risk Assessment Royal Medical Services The University of Jordan. American International Journal of Contemporary Research, 4(4), 112-119.

17. Moore, Z., \& Cowman, S. (2012). Pressure ulcer prevalence and prevention practices in care of the older person in the Republic of Ireland. Journal of Clinical Nursing, 21(3-4), 362-371. https://doi.org/10.1111/j.13652702.2011.03749. $x$ 